\title{
A Case Study in the Use of 3-Dimensional Ground Water Modeling and Solute Transport Engines as a Tool in Site Assessment
}

\author{
Jason Nolan ${ }^{1}$, Samuel Watts ${ }^{2}, \&$ Bertha Proctor ${ }^{3}$ \\ ${ }^{1}$ Department of Earth and Atmospheric Sciences, University of Nebraska-Lincoln, Lincoln, NE, USA \\ ${ }^{2}$ Department of Geography, Minnesota State University, Mankato, Mankato, MN, USA \\ ${ }^{3}$ Department of Biological Sciences, Minnesota State University, Mankato, Mankato, MN, USA \\ Correspondence: Jason Nolan, 214 Bessey Hall, Department of Earth and Atmospheric Sciences, University of \\ Nebraska-Lincoln, Lincoln, NE 68588, USA. E-mail: Jason.nolan@unl.edu
}

Received: January 6, 2014 Accepted: March 13, 2014 Online Published: March 17, 2014

doi:10.5539/ep.v3n2p55 URL: http://dx.doi.org/10.5539/ep.v3n2p55

The research was funded by the Department of Biological Sciences, Minnesota State University, Mankato

\begin{abstract}
A case study was conducted on the application of modeling in site assessment. We determined the potential for migration of 3 heavy metals and several organic compounds from a site 300 yards north of a swimming area. The site has a history of environmental issues and incidents dating back to 1985. In 2010 the Minnesota Pollution Control Agency (MPCA) measure levels from 638 to $6847 \mathrm{mg} \mathrm{kg}^{-1}$ of ethyl benzene, toluene and xylenes (BTEX) compounds in manholes, tanks, and soil on the site. Previously, lead $(\mathrm{Pb})$, cadmium $(\mathrm{Cd})$ and chromium (Cr) concentrations in soil ranged from 210 to $18,000 \mu \mathrm{g} \mathrm{kg}^{-1}$. Using reactive transport models with MODFLOW, plumes were developed for metals and BTEX compounds based on data from sediment testing, geological features, and site data from MPCA. Our plume models predict that heavy metals would enter of the swimming lake through surface water runoff and a BTEX plume would enter the swimming lake and the Minnesota River through groundwater. Sediment samples from a drainage ditch adjacent to the site contained concentrations of $\mathrm{Cd}$ and $\mathrm{Cr} 10$ times higher than a nearby reference site supporting our plume results. Sediment samples also indicated that $\mathrm{Cd}$ and $\mathrm{Cr}$ concentrations decreased down gradient, further supporting model predictions. BTEX compounds were not detected in sediment or water samples during the study. We find that incorporating three-dimensional groundwater modeling into a site assessment can provide a useful estimate of a plume's direction and concentration and aid in determining future sampling locations.
\end{abstract}

Keywords: groundwater modeling, BTEX, heavy metals

\section{Introduction}

\subsection{Site Assessments}

Phase I and Phase II site assessments normally are an integral part of the buying and selling of commercial properties the United States. In following the American Society for Testing and Materials (ASTM) for Phase I site assessment, all recognized environmental conditions should be identified (ASTM, 2005). However, if a Phase I site assessment indicates a high probability of contamination, a Phase II assessment should be completed (ASTM, 2005). Currently, Phase I site assessments do not incorporate groundwater modeling as a standard practice (Federal Register, 2005). However, groundwater-modeling software may provide useful insight in estimating contaminant transport and fate and in determining sampling locations for the Phase II.

This case study focuses on an industrial site (referred to as the "site"), which is located at 110 West Lind Street in Mankato, MN. The site is located 300 yards north of a City Park and an 18 acres public swimming area known as Hiniker Pond (Figure 1). From 1966-2010 an industrial preparation, painting and welding facility was in operation on the site until it was sold in the fall of 2010. While doing excavation work, the new owner discovered previously undocumented underground tanks. 


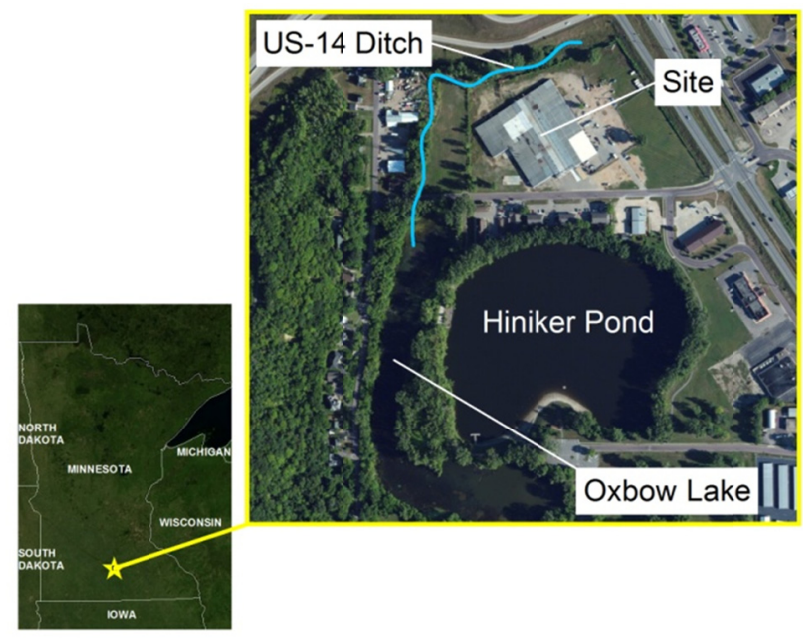

Figure 1. Location of Hiniker Pond and the "site" (inset), Mankato, MN

The Minnesota Pollution (MPCA) was notified and took a series of samples. The MPCA found organic chemicals, including toluene, ethyl benzene, and the three isomers of xylene. These organic chemicals along with benzene (not found on site) are collectively known as BTEX. Tests conducted by the MPCA on September 24, 2010 found high levels of ethyl benzene $\left(1,901 \mathrm{mg} \mathrm{kg}^{-1}\right)$, toluene $\left(338 \mathrm{mg} \mathrm{kg}^{-1}\right)$, and meta/para-xylenes $\left(6,847 \mathrm{mg} \mathrm{kg}^{-1}\right)$, in manhole that accesses to the storage tanks (MPCA, 2010). These compounds were utilized as part of the metal preparation and cleaning process that occurred before the painting process (MPCA, 2010).

There is a history of environmental concerns (water, soil, drums containing hazardous waste, improper disposal methods and disregarding administrative orders issued by the MPCA) at the site that date back to 1985 (MPCA 2010; State of Minnesota, 1985). In July 1985, soil samples collected on the site at 1-1.5 ft. depth from 4 holes (\#s 16, 18, 19, 20) were found to contain $200 \mathrm{mg} \mathrm{kg}^{-1}$ of toluene and xylenes and over $50 \mathrm{mg} \mathrm{kg}^{-1}$ of ethyl benzene (State of Minnesota, 1985). In addition soil samples also contained chromium $\left(18,000 \mu \mathrm{g} \mathrm{kg}^{-1}\right)$, lead $\left(520 \mu \mathrm{g} \mathrm{kg}^{-1}\right)$ and Cadmium $\left(210 \mu \mathrm{g} \mathrm{kg}^{-1}\right)$ (State of Minnesota, 1985).

The MPCA has confirmed that manholes found on the site and 2 floor drains located in the buildings where metal preparation and painting mostly likely occurred (site map 4 in MPCA, 2010) drain directly into the US-14 ditch (MPCA, 2010). This ditch flows into a small oxbow lake that is connected to Hiniker Pond, a popular public swimming area. A paint washing system and additional underground storage tanks (previously unknown) that improperly empty into a drainage field were also found on the site (MPCA, 2010).

\subsection{BTEX}

BTEX compounds are found in many petroleum products including gasoline, fuel oil, and occur in a wide variety of industrial cleaning supplies (Chang Chien et al., 2010). While Benzene was not found on our case study site, toluene, ethyl benzene and 3 isomers of xylene $(0, p, m)$ were. Toluene and xylenes (total) compounds pose a significant risk to human health when present at above EPA mandated Human Health Benchmarks (HHB) (López, 2008), $1 \mathrm{mg} \mathrm{l}^{-1}$ and $10 \mathrm{mg} \mathrm{l}^{-1}$ (Federal Register, 2012), respectively in drinking water. Toluene and xylenes have been associated with skin and sensory irritation, central nervous system depression and respiratory inflammation/compromise (Batlle-Aguilar et al., 2009). Based on laboratory studies with mice, prolonged exposure to these compounds can also lead to damage to the kidneys, liver and blood system (López, 2008; USDPHS, 2013). Ethyl Benzene has an EPA set limit of $0.7 \mathrm{mg} \mathrm{l}^{-1}$ (Federal Register, 2012) in drinking water, but there is limited and conflicting information on its' impacts on humans (USDPHS, 2013).

There are many processes that affect the mobility and persistence of BTEX compounds in the environment. BTEX compound degradation is highly dependent on climate as they are relatively volatile, and even trace amounts may pose a threat to aquatic organisms as well (Kahan \& Donaldson, 2010). These processes include dispersion in water, sorption by soil organic matter (SOM), volatilization into the air or into soil air spaces, and microbial degradation (Chang Chien et al., 2010; Lin, 2002; Phelps et al., 1999). Degradation is primarily dictated by the medium (water, soil, or air), as well as $\mathrm{pH}$, surface activity, and solubility (Epstein \& Chang, 1978). Sorption coupled to SOM while increasing degradation through microbial decomposition coupled to 
oxidation, can also lead to localized hot spots or preferential flow patterns as well in heterogeneous media (Chang Chien et al., 2010; Lin, 2002).

Microbial degradation of BTEX compounds not subject to volatilization is a viable means of natural attenuation in the subsurface and has been widely studied with common microorganisms (Lin, 2002). Microbial degradation is highly dependent on dissolved oxygen levels (aerobic/anaerobic), $\mathrm{pH}$, temperature, and the microbial community composition (Lin, 2002). In colder temperatures BTEX compounds degrade slower. Therefore, BTEX compounds are more persistent in areas that experience freezing temperatures for a good part of the year (Kahan \& Donaldson, 2010). Due to the persistence of these compounds under anaerobic conditions they can be potentially transported long distances (Cunningham et al., 2001).

\subsection{Heavy Metal Contamination}

Heavy metals do not degrade and tend to accumulate in organisms and systems over time, causing numerous disorders and diseases in humans (Malakootian et al., 2009). Metals found on this site were lead, cadmium, and chromium (MPCA, 2013; Jarup, 2003).

Lead exposure is one of the most common toxic exposures to humans in the $20^{\text {th }}$ century. Lead has a history of causing permanent neurologic damage and has been linked to lowered IQ scores in adults when exposed during childhood (Jarup, 2003). While the half-life of $\mathrm{Pb}$ in the blood is only usually 1 month, it can persist in the skeleton for up to 30 years (Jarup, 2003). Long-term exposures to lead can cause peripheral nervous system deterioration, psychosis, reduced consciousness, and death. Lead forms commonly forms insoluble compounds in an aqueous environment making it less mobile as well (Wang et al., 2001).

The health effects of cadmium include kidney damage, particularly damage to tubules, resulting from renal lesions, and an increase in kidney stones. Long-term exposure can cause mineralization of the bones or early onset osteoporosis, similar to that seen in Japan with the Itai-Itai (ouch-ouch) disease incident (Jarup, 2003).

Chromium is used extensively as a pigment in paints, industrial paint primers, electroplating, and steel productions (Goldoni et al., 2006). It has two oxidation states, trivalent (Cr III) and hexavalent (Cr VI). Chromium (III) is naturally occurring in the environment, is needed in the body as an essential nutrient and its toxicity is considered to be very low (Demir \& Arisoy, 2007). Chromium (VI) does not normally occur in the environment, is recognized as being highly toxic, and classified as a Class I human carcinogen by the International Agency for Research on Cancer (IARC) (Goldoni et al., 2006).

The movement of metals in soil, surface water, and in ground water can be very complex. In soils the transport, fate, mobilization, or immobilization of these metals are controlled by a range of factors that include: $\mathrm{SOM}, \mathrm{pH}$ (soil acidity), the metal species (oxidized or reduced form dependent on anaerobic or aerobic conditions), and Cation Exchange Capacity (CEC) of the soils (Baumann et al., 2006). Heavy metals applied to soils will be immobilized through REDOX (dependent on dissolved oxygen) reactions, adsorption by colloids, bind with soil organic matter, or be taken up by plants (Epstein \& Chaney, 1978).

\subsection{Modeling}

MODFLOW was developed by the USGS in 1983 as a finite modular three-dimensional ground water flow computer code. The MODFLOW code can be used by a number of interfaces and allows for the addition of add-on packages to trace particle flow or contamination spread (USGS, 2009). MODFLOW is accepted as an industry standard both in North America as well as in Europe to model groundwater flows (Gao, 2011). In MODFLOW, layers are setup to represent three-dimensional lattices of the earth based on soil, aquifer, and bedrock properties and dimensions (Prommer et al., 2002).

MODFLOW requires that you add surface terrain elevations and hydrological features such as constant head boundaries, sinks, rivers, and lakes. These features determine the direction and amount of flow of groundwater in the model. Evapotranspiration and annual recharge values must be added as well. Known head values from well and boring logs are used to increase the accuracy of the model and the output will be in the form of a potentiometric map showing flow directions, velocities, flux, boundaries (Gao, 2011). The output from this step is saved and can be used later to determine contaminant transport and estimate pollution spread.

Contaminant transport engines are used once a basic MODFLOW solution has been achieved. There are numerous free contaminant transport engines available to use with MODFLOW. These include MT3DMS, RT3D, and PHT3D. These engines use a finite difference upstream solution that is capable of accounting for natural degradation, dispersion, and diffusion, which can be based on calculated or default values including sulfate reduction, nitrate reduction, and the difference in aquifer materials (Prommer et al., 2002). When using MT3DMS, developed by the USGS, electron receptors are used to determine sorption along with the option of 
using a Freundlich or Langmuir adsorption isotherm curve (Shlumberger Water Services, 2010). The engine PHT3D uses the same method, but takes into account the USGS geochemical code PHREEQC-2 that predicts fate based on constant and default parameters (Shlumberger Water Services, 2010). The RT3D engine is similar to the MT3DMS engine, but is specifically designed to work with BTEX compounds. Standard normalized values for sulfates, irons, and oxygen based on common aquifer properties of this type can be used coupled with default isothermal constants to simulate natural sorption and biodegradation in most aquifer types (Prommer et al., 2002).

\subsection{Study Objectives}

The objectives of this research were to develop a ground water model utilizing USGS MODFLOW coupled with solute transport engines to predict the transport and fates of BTEX and heavy metals from the site. We analyzed surface water and sediment samples from US 14 Ditch, Oxbow Lake, Hiniker Pond and a control pond (Hallett's pond) to determine whether levels heavy metals and BTEX compounds supported the modeling results.

\section{Methods}

\subsection{Modeling}

Visual MODFLOW Premier, a Graphical User Interface (GUI) from Schlumberger Water Services Inc. that uses the USGS MODFLOW computer code was used to build a three-dimensional model of subsurface water flow. The model cell area covered 5 square miles and included area around Hiniker Pond and Oxbow Lake, with US-14 ditch as the northern boundary and the Minnesota River on the Eastern boundary. An annual recharge rate of 28 inches per year and an annual evapotranspiration rate of 23 inches per year were applied to the model based local data (Delin et al., 2007). Hiniker Pond and Oxbow Lake were added as lake features, using depths provided by Minnesota DNR (Minnesota DNR, 2007). The Minnesota River was added as a river boundary using an average depth of 12 feet (Minnesota DNR, 2007). Both the lake and river boundary areas and shapes were input by tracing the features on the local digital quadrangle.

The surface layer of the model was based on the latest soil survey completed in 1983 by the Natural Resource Conservation Service (NRCS) (NRCS, 1984). Topographical data were retrieved from the USDA digital database with 2-foot elevation differentials and applied to the surface to show terrain. This layer was made 5 feet thick based on a boring report from the Minnesota Department of Transportation from 1969 at the US-14 overpass from the north, the NRCS soil survey report, and the report by the USDPH on the old North Mankato dump on the south (USDPHS, 2001).

The second layer of the model was designed using values that were calculated in the lab. A sample of aquifer material was collected from 2 feet below the sediment of Hiniker Pond. The conductivity was calculated from a constant head test conducted using a piezometer following standard USGS accepted methods (Fetter, 1994). Porosity and bulk density were calculated using a Quantachrome ${ }^{\circledR}$ pycnometer using a method described elsewhere (Lowell, 2004). The equations, reports, and data used to determine final values are presented in the Supplementary Material. The elevation of the top of layer two was determined using the top layer elevation data and using ARC GIS to subtract five feet from it to represent the assumed thickness of the top layer. The bottom of layer two was set to the bedrock, known to be at about 700 feet above sea level from the geological atlas for Nicollet County, MN (Water Resource Center-Minnesota State University-Mankato, 2002).

The values for the last layer, the bedrock, were set to near to zero as possible and the layer was made 1 foot thick with a slight elevation change from 700 feet on the south to 693 feet on the north based on the geological atlas and US-14 boring report (Minnesota Department of Transportation, 1969; Water Resource Center-Minnesota State University-Mankato, 2002). Values that were required for each layer included storativity, specific yield, conductivity, and porosity; they were calculated using equations or available data as presented in Supplementary Material. MODFLOW was set to 9,990 days (27 years approximately) to represent the total time frame that the previous company had been in business (MPCA, 2010).

\subsubsection{Heavy Metal Transport}

MT3DMS was used as the engine to predict heavy metal transport using lead as the surrogate. This engine is the best choice when biodegradation is not a factor when dealing with heavy metals that are persistent (Prommer et al., 2002). The adsorption coefficients were also most appropriate with the MT3DMS engine with lead only having one oxidation state. Geochemical modeling of the chromium concentrations in PHREEQC-2 indicated that very minimal hexavalent chromium $\left(10^{-8} \mathrm{~mol}\right)$ would dissociate with the underlying reduced groundwater conditions in this area. Therefore, lead was used as a surrogate. The initial concentration of lead was based on 
the assumption of a constant leakage of $1 \mathrm{mg} \mathrm{l}^{-1}$ per day for 9,990 days (27 years). This was the best estimate of constant leakage from the paint tanks on the site since the first complaint in 1985 (MPCA, 2010).

A Langmuir sorption curve was used with values calculated from sediment testing and previous studies on similar sediment types (see supplementary). Langmuir was used over Freundlich due to the losses from a single spill incident assumed to be two orders of a magnitude greater through the ground and a very little clay in the soils of the region minimizing additional sorption sites. The engine was run using the conductivity for the media as calculated in the lab of 59 feet per day horizontally. Vertical conductivity was set to 5.9 feet per day based on default vertical conductivity solutions in the model. Changing of the conductivity, dispersivity, and adsorption coefficients were done for sensitivity analysis and to parameter adjustment. This process allowed the groundwater model to be delineated for the maximum, minimum, and most probable extent of the plume. The model was run for numerous iterations and outputs were recorded at different time intervals to show the size and extent of the heavy metal (lead as a surrogate) plume.

\subsubsection{BTEX Transport}

The RT3D transport engine was used to model BTEX compound transport of a simulated leak. The engine was chosen because of the available built in default parameters for sulfates, iron, and oxygen in the soil and the chemical properties of BTEX already existing in the code. The option of using a first order engine was used with default values to simulate an aerobic environment for biological degradation to occur. The initial concentration for the BTEX plume was based on the assumption of a constant release of $1 \mathrm{mg} / \mathrm{L}$ per day for 5 years. Toluene was used as the surrogate for BTEX compounds. A Langmuir adsorption curve was used due to the chemical properties of BTEX based on previous studies (Prommer et al., 2010). Aquifer properties were manipulated from the calculated values to determine the maximum, minimum, and most probable extent of contamination. Aquifer properties in the model were similar to that used for heavy metals (see supplementary). The model was run again for numerous iterations and outputs were recorded at different time intervals to show the size and extent of the BTEX plume.

\subsection{Field Sampling}

Water and sediment samples were collected from Hiniker Pond, Hallett's Pond, Oxbow Lake and US-14 ditch in May 2011. Water was collected at the surface and the deepest point for Hiniker Pond and Hallett's Pond and at the surface for US-14 ditch and Oxbow lake. Sediment samples were also collected from the deepest water in Hiniker Pond and Hallett's Pond. Sediments were collected from Oxbow Lake and US-14 ditch from the lowest lying areas. Samples were collected using standard EPA methods and transported to the EPA Certified Laboratory, Minnesota Valley Testing Laboratory, New Ulm, MN (MVTL). All collection procedures and analytical methods conform to U.S. EPA protocols (US EPA, 1996).

\section{Results}

\subsection{Modeling}

The MODFLOW simulation showing the heavy metal plumes were simulated using the MT3DMS engine using values presented in the Supplementary Material. Figures 2 and 3 show the heavy metal plume (lead as indicator) modeled by various time stages, 30 days and 1 year, respectively (animation available in supplemental materials). As the plume undergoes advection and slowly diffuses laterally, it makes contact with the Minnesota River but never contacting Hiniker Pond or Oxbow Lake through subsurface flow. Using higher and lower conductivities, adsorption coefficients, and dispersivity values, minimum, maximum, and most probable cases of contamination showed negligible difference in the size and extent of the contamination plume. These numbers were determined by using $+/-1$ Standard Deviation for each of the input values leading to a thorough sensitivity analysis. Only when dispersivity was increased to 100 times the calculated conductivity of the aquifer material, did the lead plume reach Hiniker Pond and Oxbow Lake. However, this scenario is not realistic. 

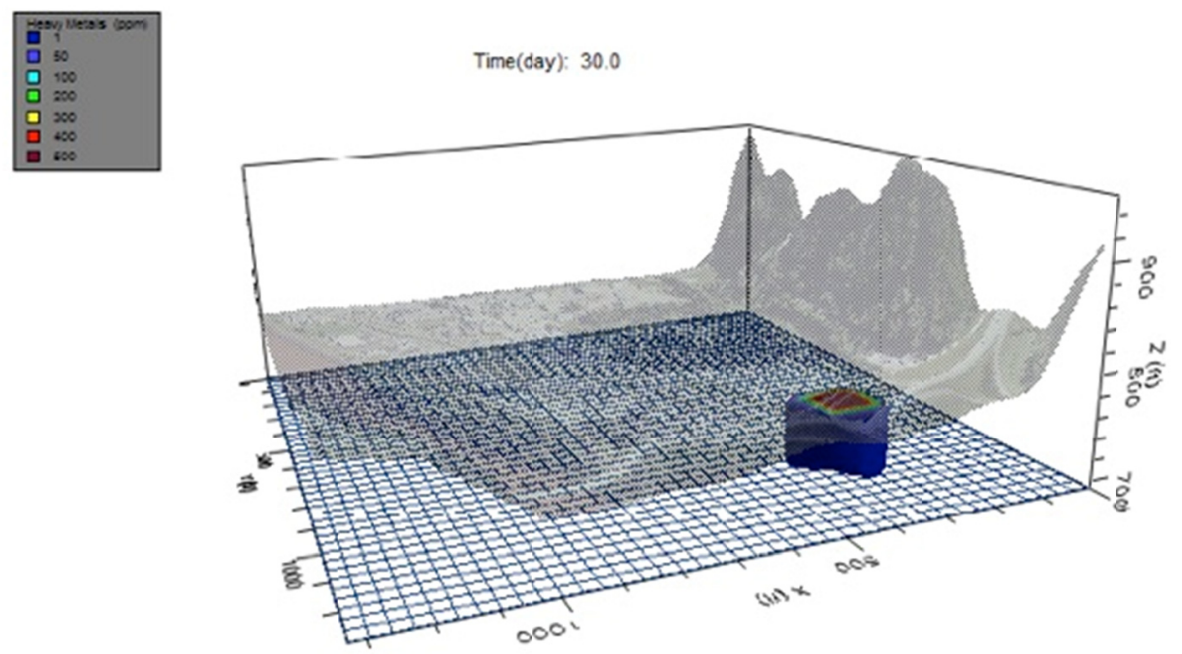

Figure 2. Estimated heavy metal plume (lead as a surrogate) from the site after 30 days
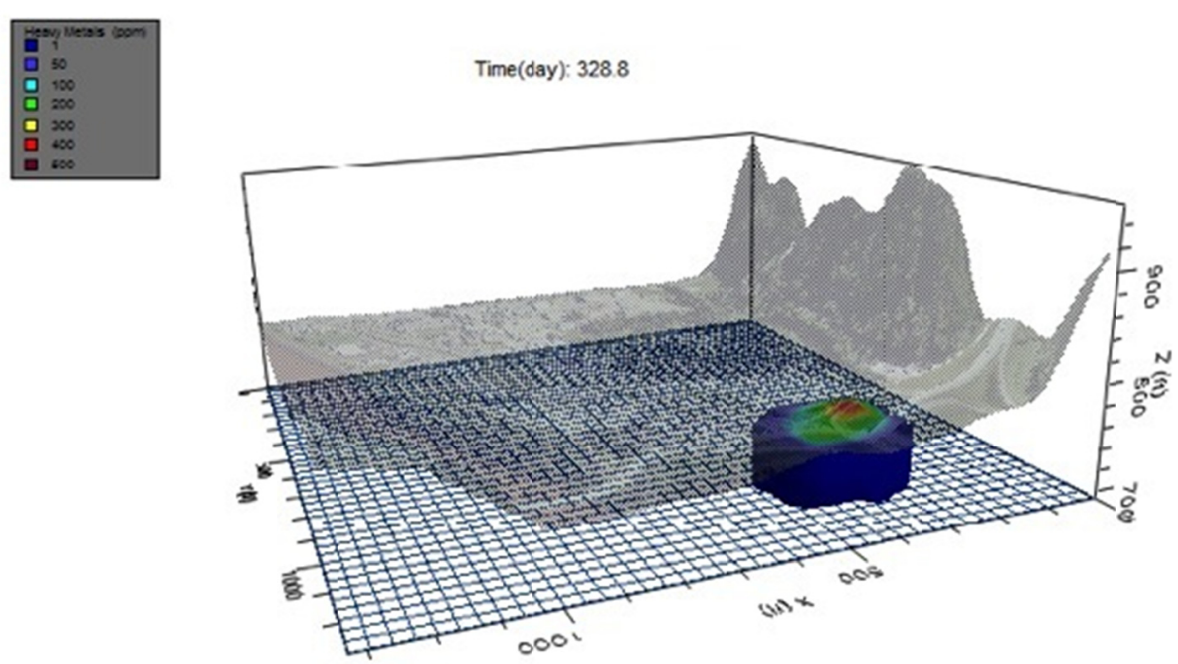

Figure 3. Estimated heavy metal plume (lead as a surrogate) from the site after 329 days

The BTEX plumes were modeled using the RT3D engine. The properties of the layers and the model were not changed from the conditions used to model the lead plumes. The BTEX plume models can be seen in Figures 4 and 5 at intervals of 30 days and 90 days respectively. The values of conductivity and dispersivity to obtain minimum, maximum, and most probable cases of contamination were calculated by using plus or minus one standard deviation of the averages as with heavy metals. This sensitivity analysis showed no discernable or relevant impact on the general shape, size, or final concentration of the BTEX contamination plume. The plume contacts both Hiniker Pond and Oxbow Lake within 30 days as seen in Figure 4, and continues to grow until it makes contact with the Minnesota River at about one year, and then shrinks as it flows into the river. Sensitivity analysis cases also contacted Hiniker Pond and Oxbow Lake in less than 30 days and the Minnesota River slightly before or after one year, but within a few days. 


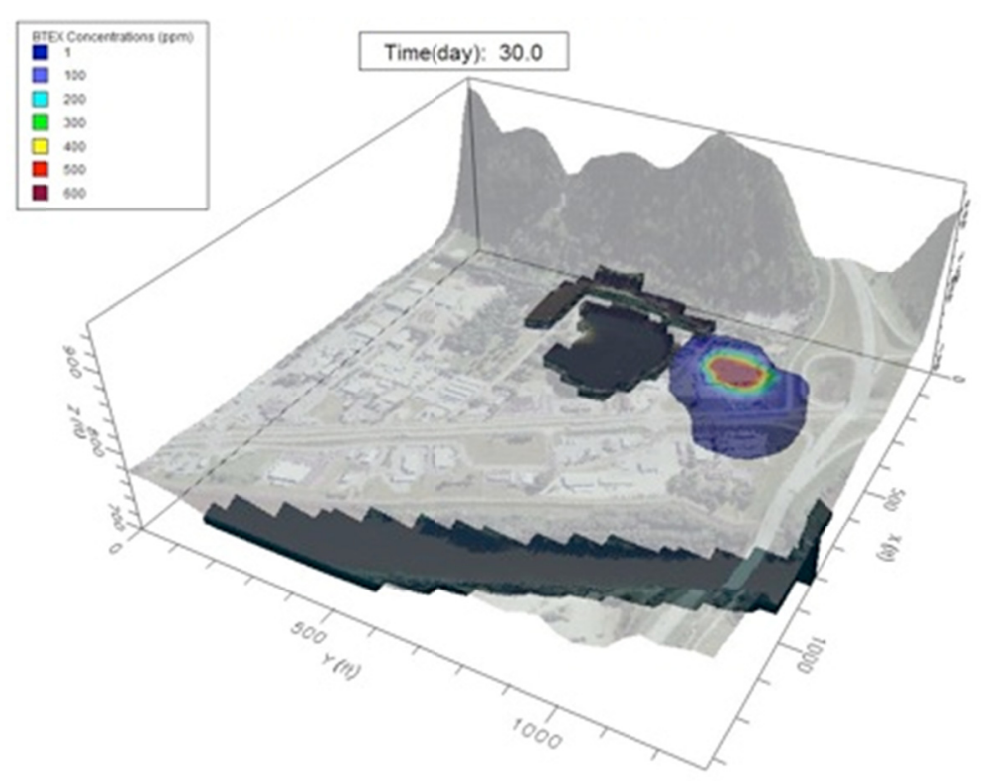

Figure 4. Estimated BTEX plume (toluene as a surrogate) from the site after 30 days

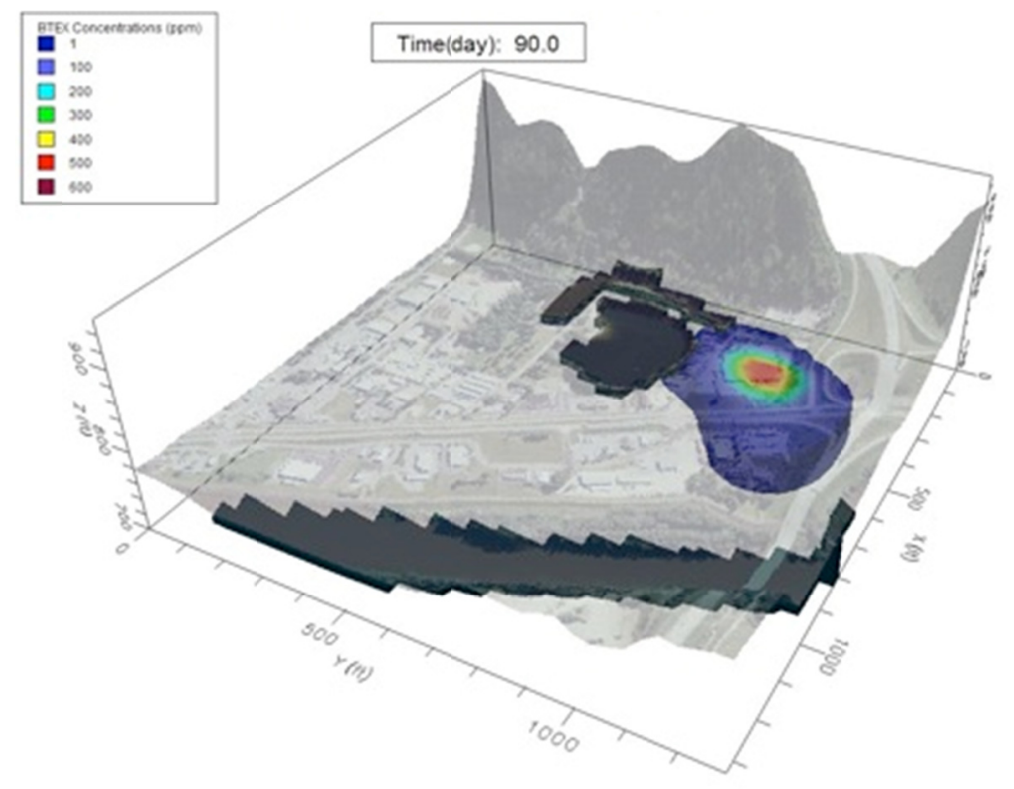

Figure 5. Estimated BTEX plume (toluene as a surrogate) from the site after 90 days

\subsection{Water and Sediment Sampling}

Ethyl benzene, toluene, and $\mathrm{m} / \mathrm{p} / \mathrm{o}$ xylenes levels were below the limits of detection in all the water and sediment samples (data not shown). The $\mathrm{Pb}, \mathrm{Cd}$ and $\mathrm{Cr}$ sediment data are presented in Table 1. The highest levels of heavy metals in sediment samples were found in US-14 Ditch (closest to the site). Levels of metals decreased with increasing distance from the site. These metals were not detected in the water samples. 
Table 1. Concentration of cadmium, chromium and lead in sediments

\begin{tabular}{cccc}
\hline Water Body & Cadmium $\left(\mu \mathrm{g} \mathrm{kg}^{-1}\right)$ & Chromium $\left(\mu \mathrm{g} \mathrm{kg}^{-1}\right)$ & $\mathrm{Lead}\left(\mu \mathrm{kg}^{-1}\right)$ \\
\hline US 14 Ditch & $1,250.0$ & $20,700.0$ & $30,800.0$ \\
Oxbow Lake & 471.0 & $11,600.0$ & $7,010.0$ \\
Hiniker Pond & 208.0 & $3,490.0$ & $<694.0$ \\
Hallett's Pond & 129.0 & $2,010.0$ & $<709.0$ \\
\hline
\end{tabular}

Description: Levels of heavy metals $(\mathrm{Cd}, \mathrm{Pb}, \mathrm{Cr})$ in sediment samples by increasing distance from the site. Hallet's pond serves as a nearby reference site.

\section{Discussion}

\subsection{BTEX}

The field sampling was limited by financial constraints and limited access to US 14 ditch, Oxbow Lake and no access to the site. In addition, only surface samples were collected in US 14 Ditch during non-storm events. However, BTEX compounds in soil were found at the site at depths of 1-1.5 feet in 1985 and at an even greater depth in 2010 (manholes) (MPCA, 2010). Given the documented contamination by the MPCA together with field observations such as discolored soils and heavy sheening observed on US-14 ditch and Oxbow lake, it likely that hydrocarbons were present at the site after storm events due to flushing or overflow of storage tanks, drain pipes and soils. If or when access and additional funding become available, we recommended that water and sediments after be collected during and after several storm events.

Every modification of the Terminal Electron Accepter Process (TEAP) model, decay rate changes (seasonal climate variations), as well as the physical characteristic changes of the layer/aquifer materials such as conductivities and porosities indicated that if BTEX compounds were released from the site, they would reach Hiniker Pond through ground water.

Sensitivity Analyses (+/- 1 Std. Dev.) indicated no substantial changes to the plume direction, size, or longevity. BTEX compounds reached Hiniker Pond through groundwater within 7 to 30 days of release. This conclusion is supported by Lopez et al. (2008) research that found the quick dispersion of these compounds and in groundwater.

\subsection{Heavy Metals}

Chromium, $\mathrm{Pb}$ and $\mathrm{Cd}$, were found in sediment samples but were below the limit of detection in the water samples. US-14 ditch sediments had approximately 30 times higher levels of $\mathrm{Pb}$ and 10 times higher levels of $\mathrm{Cd}$ and $\mathrm{Cr}$ than sediments from Hallett's Pond (background reference site). Both $\mathrm{Cd}$ and $\mathrm{Cr}$ are commonly used in industrial paints. The sediment metal data suggest that the site is a source of $\mathrm{Pb}, \mathrm{Cd}$, and $\mathrm{Cr}$ and that they are transported through surface water runoff. However, the proximity of the US-14 ditch to the highway does create the possibility of an unknown source of contamination. Additional sites should be selected based on modeling results to confirm these findings. Using $\mathrm{Pb}$ as a representative of heavy metals, the MODFLOW MT3DMS model indicated that the metals are most likely being transported by surface runoff, which agrees with our field assessment findings.

Based on sensitivity analyses, no substantial changes in the plume's direction, size, longevity, or fate were indicated when sorption sites and physical characteristics (vertical/horizontal conductivities and porosity) were modified (+/- 1 Std. Dev). In all scenarios, heavy metals did not reach Hiniker Pond through groundwater transport.

Continued and more extensive sampling of surface water, ground water, soils and sediments are necessary to better assess if the site has any impacts on Hiniker pond. Results of plume modeling should be useful in selecting future sampling sites for this purpose. More monitoring data will also allow for model verification and refinement to aquifer properties.

\subsection{Model Applicability in Site Assessment}

Groundwater modeling is a valuable tool when applied to site assessment. With the increase demands for site assessment and forensic geology, groundwater models/contaminant transport engines should become part of the tool kit. With the rapid expansion in free software being offered by agencies such as PHREEQC-3, PHAST, and MODFLOW (USGS, 2009), the costs are decreasing. These models are flexible (multiple layers and complex 
chemical mixtures) and relatively efficient to run with parallel computing abilities that are commonplace in today's industry (Shlumberger Water Services, 2012). Groundwater modeling could be an effective tool as part of a Phase I site assessment given the inherent limitations and unknowns of a groundwater system (Safavi et al., 2010).

\section{References}

ASTM. (2005). E1527-05. Standard Practice for Environmental Site Assessments: Phase I Environmental Site Assessment Process.

Batlle-Aguilar, J., Brouyère, S., Dassargues, A., Morasch, B., Hunkeler, D., Höhener, P., ... Halen, H. (2009). Benzene dispersion and natural attenuation in an alluvial aquifer with strong interactions with surface water. Journal of Hydrology, 369(3), 305-317. http://dx.doi.org/10.1016/j.jhydrol.2009.02.014

Baumann, T., Fruhstorfer, P., Klein, T., \& Niessner, R. (2006). Colloid and heavy metal transport at landfill sites in direct contact with groundwater. Water Research, 40(14), 2776-2786. http://dx.doi.org/10.1016/j.watres.2006.04.049

Chang Chien, S. W., Chen, C. Y., Chang, J. H., Chen, S. H., Wang, M. C., \& Mannepalli, M. R. (2010). Sorption of toluene by humic acids derived from lake sediment and mountain soil at different $\mathrm{pH}$. Journal of Hazardous Materials, 177(1-3), 1068-1076. http://dx.doi.org/10.1016/j.jhazmat.2010.01.029

Cunningham, J. A., Rahme, H., Hopkins, G. D., Lebron, C., \& Reinhard, M. (2001) Enhanced in situ bioremediation of BTEX-contaminated groundwater by combined injection of nitrate and sulfate. Environmental Science Technology, 35, 1663-1670. http://dx.doi.org/10.1021/es001722t

Delin, G. N., Healy, R. W., Lorenz, D. L., \& Nimmo, J. R. (2007). Comparison of local-to regional-scale estimates of ground-water recharge in Minnesota, USA. Journal of Hydrology, 334(1), 231-249. http://dx.doi.org/10.1016/j.jhydrol.2006.10.010

Demir, A., \& Arisoy, M. (2007). Biological and chemical removal of Cr (VI) from wastewater: Cost and benefit $\begin{array}{lllll}\text { analysis. Journal of Hazardous } & \text { Materials, } & \text { 147(1-2), }\end{array}$ http://dx.doi.org/10.1016/j.jhazmat.2006.12.076

Epstein, E., \& Chaney, R. L. (1978). Land disposal of toxic substances and water-related problems. Water Pollution Control Federation, 50(8), 2037-2042. http://www.jstor.org/stable/25040382

Federal Register. (2005). Standards and Practices for All Appropriate Inquiries. US EPA. Volume 70, Number 210. Final Rule Published November 1, 2005.

Federal Register. (2012). National Primary Drinking Water Regulations. US EPA. Volume 24, Title 40, Part 141.61 "Maximum Contaminant Levels for Organic Compounds." Final Rule.

Fetter, C. W. (1994). Applied hydrology. Mac Millan.

Gao, H. (2011). Groundwater modeling for flow systems with complex geological and hydrogeological conditions. Procedia Earth and Planetary Science, 3(0), 23-28. http://dx.doi.org/10.1016/j.proeps.2011.09.061

Goldoni, M., Caglieri, A., Poli, D., Vettori, M. V., Corradi, M., Apostoli, P., \& Mutti, A. (2006). Determination of hexavalent chromium in exhaled breath condensate and environmental air among chrome plating workers. Analytica Chimica Acta, 562(2), 229-235. http://dx.doi.org/10.1016/j.aca.2006.01.065

Jacques, D., Šimůnek, J., Mallants, D., \& Van Genuchten, M. T. (2008). Modelling coupled water flow, solute transport and geochemical reactions affecting heavy metal migration in a podzol soil. Geoderma, 145(3), 449-461. http://dx.doi.org/10.1016/j.geoderma.2008.01.009

Järup, L. (2003). Hazards of heavy metal contamination. British Medical Bulletin, 68(1), 167-182. http://dx.doi.org/10.1093/bmb/ldg032

Kahan, T. F., \& Donaldson, D. J. (2010). Benzene photolysis on ice: Implications for the fate of organic contaminants in the winter. Environmental Science \& Technology, 44(10), 3819-3824. http://dx.doi.org/10.1021/es100448h

Lin, B., Van Verseveld, H. W., \& Roling, W. F. M. (2002). Microbial aspects of anaerobic BTEX degradation. Biomedical and Environmental Sciences, 15(2), 130-144.

López, E., Schuhmacher, M., \& Domingo, J. L. (2008). Human Health Risks of Petroleum-Contaminated Groundwater: A Case Study. Env Sci Pollut Res, 15(3), 278-288. http://dx.doi.org/10.1065/espr2007.02.390 
Lowell, S. (Ed.). (2004). Characterization of porous solids and powders: surface area, pore size and density, 16, 327. Springer.

Malakootian, M., Nouri, J., \& Hossaini, H. (2009). Removal of heavy metals from paint industry's wastewater using leca as an available adsorbent. International Journal of Environment Science Technology, 6(2), 183-190. http://dx.doi.org/10.1007/BF03327620

Minnesota Department of Natural Resources. (2007). Lake Finder Information- Hiniker pond. Retrieved August 13, 2013, from http://www.dnr.state.mn.us/lakefind/index.html

Minnesota Department of Transportation. (1969). Boring Report US-14 Bridge at US-169, North Mankato, MN.

Minnesota Pollution Control Agency. (2010). "Year-A-round" Case Development Form; Known Subsurface to Surface Drainage, Year-A-Round Site. Preliminary Lab Results of Manhole Sludge at "Year-A-Round" Site.

Natural Resource Conservation Service. (1983). Complete Soil Survey of Nicollet County, Minnesota. (Paper edition). Retrieved from http://websoilsurvey.sc.egov.usda.gov/App/HomePage.htm

Peters, R. W. (1999). Chelant extraction of heavy metals from contaminated soils. Journal of Hazardous Materials, 66(1-2), 151-210. http://dx.doi.org/10.1016/S0304-3894(99)00010-2

Phelps, C. D., \& Young, L. Y. (1999). Anaerobic biodegradation of BTEX and gasoline in various aquatic sediments. Biodegradation, 10(1), 15-25. http://dx.doi.org/10.1023/A:1008303729431

Prommer, H., Barry, D. A., \& Davis, G. B. (2002). Modeling of physical and reactive processes during biodegradation of a hydrocarbon plume under transient groundwater flow conditions. Journal of Contaminant Hydrology, 59(1-2), 113-131. http://dx.doi.org/10.1016/S0169-7722(02)00078-5

Sabty-Daily, R., Luk, K., \& Froines, J. (2002). The efficiency of alkaline extraction for the recovery of hexavalent chromium from paint samples and the effect of sample storage on $\mathrm{Cr}(\mathrm{VI})$ recovery. The Analyst, 6, 852-858. http://dx.doi.org/10.1039/b106701j

Safavi, H. R., Darzi, F., \& Mariño, M. A. (2010). Simulation-optimization modeling of conjunctive use of surface water and groundwater. Water resources management, 24(10), 1965-1988. http://dx.doi.org/10.1007/s11269-009-9533-z

Shlumberger Water Services. (2012). Visual MODFLOW Premium Overview. Retrieved July 20, 2010, from http://www.swstechnology.com

State of Minnesota. (1985). Memorandum Concerning Year-A-Round Cab Company. Report to Attorney General's office. (Available through MPCA).

U.S. Department of Public Health and Human Services. (2001). Health Consultation, North Mankato Dump. Final Report.

U.S. Department of Public Health and Human Services. (2013). Agency for toxic Substances and Disease Registry. Retrieved August 13, 2013, from http://www.atsdr.cdc.gov

US EPA. (1996). Standard Method 1669, Sampling Ambient Water for trace Metals at EPA Water Quality Criteria Levels.

U.S. Geological Survey. (2009). U.S. Geological Survey Groundwater Modeling Software: Making Sense of a Complex Natural Resource. Fact Sheet 2009-3105.

Wang, Y. M., Chen, T. C., Yeh, K. J., \& Shue, M. F. (2001). Stabilization of an elevated heavy metal contaminated site. Journal of Hazardous Materials, 88(1), 63-74 http://dx.doi.org/10.1016/S0304-3894(01)00289-8

Water Resource Center, Minnesota State University. (2002). 200 Years of the Minnesota River. Informational Pamphlet.

\section{Copyrights}

Copyright for this article is retained by the author(s), with first publication rights granted to the journal.

This is an open-access article distributed under the terms and conditions of the Creative Commons Attribution license (http://creativecommons.org/licenses/by/3.0/). 